\title{
ASPEK PERLINDUNGAN ANAK DALAM PEMBERIAN SANKSI OLEH GURU TERHADAP SISWA
}

\author{
Agus Gandara \\ Pascasarjana UIN Sunan Gunung Djati Bandung \\ Email: agus.gandara@yahoo.com
}

\begin{abstract}
Abstrak
Berdasarkan hasil penelitian yang dilakukan oleh UNICEF (2006) di beberapa daerah di Indonesia menunjukkan bahwa sekitar $80 \%$ kekerasan yang terjadi pada siswa dilakukan oleh guru, padahal guru sebagai orang tua kedua para siswa di sekolah sepatutnya menjadi seseorang yang mampu menciptakan suasana yang nyaman di lingkungan sekolah sebagai tempat yang selama ini dipercaya paling aman dan terbaik untuk anak. Hasil penelitian menunjukan bahwa Undang-Undang Nomor 17 Tahun 2016 Tentang perlindungan Anak secara tegas menyatakan bahwa anak di dalam dan di lingkungan sekolah wajib dilindungi dari tindakan kekerasan yang dilakukan oleh guru, pengelola sekolah atau teman-temannya di dalam sekolah yang bersangkutan, atau lembaga pendidikan lainnya. Undang-Undang tersebutmenyatakan setiap orang yang melakukan kekejaman, kekerasan atau ancaman kekerasan, atau penganiayaan terhadap anak, dipidana dengan pidana penjara dan/atau denda. Demikian pula pemberian sanksi yang dilakukan pendidik terhadap peserta didik di lingkungan pendidikan termasuk kategori tindak kekerasan jika pemberian sanksi tersebut melukai dan atau mencederai anak dan tidak semata-mata fisik, tetapi juga mental dan sosial namun demikian dalam peraturan pemerintah nomor 19 tahun 2017 tentang guru, memberikan kewenangan kepada guru untuk memberikan sanksi kepada siswa yang dianggap melanggar peraturan sekolah.
\end{abstract}

\section{Kata Kunci : Guru, Siswa dan Perlindungan Anak}

\begin{abstract}
Based on a survey conducted by UNICEF in 2006 in several regions in Indonesia, found that $80 \%$ violence that happened toward students were done by their teachers, where the teacher should be act as students' second parents at school, who should provide and create a comfortable and secure place for the children. The results showed that the law number 17 Year 2016 on child protection explicitly states that children at school environment must be protected from any acts of violence committed by teachers, school administrators, friends at school, and other educational institution. The constitution states any person who commits cruelty, violence or threats of violence, or child abuse, punished by imprisonment or fines. Similarly if there are sanctions given by educators on learners in an educational environment will be included as category of violence if the sanctions hurt or injure the child not merely physical but also mental and social, but the goverment regulations number 19 of 2017 concerning teacher, provinding authority to teacher to sanction students who are considered violating school regulations.
\end{abstract}

Key Word: Teacher, Students and Child Protection 


\section{Pendahuluan}

Anak adalah amanah dan karunia Tuhan Yang Maha Esa, yang dalam dirinya melekat harkat dan martabat sebagai manusia seutuhnya. Lebih lanjut konsiderans Undang -undang nomor 17 tahun 2016 menyebutkan pula bahwa anak adalah tunas, potensi, dan generasi muda penerus cita-cita perjuangan bangsa, memiliki peran strategis dan mempunyai ciri dan sifat khusus yang menjamin kelangsungan eksistensi Bangsa dan Negara pada masa depan. ${ }^{1}$

Berkaitan dengan hal tersebut di atas maka perlindungan terhadap anak harus benar-benar diwujudkan dalam waktu, tempat dan kondisi seperti apapun anak itu berada di lingkungan keluarga/tempat tinggalnya, di lingkungan masyarakat dan dilingkungan pendidikan/sekolahnya di lingkungan-lingkungan tersebut anak harus mendapatkan kesempatan yang seluas-luasnya untuk tumbuh dan berkembang secara optimal, baik fisik, mental maupun sosial disamping itu pula anak harus mendapatkan jaminan terhadap pemenuhan hak-haknya serta adanya perlakuan tanpa diskriminasi dan kekerasan.

Perlindungan terhadap anak dewasa ini belum dapat terwujud secara maksimal baik ketika kondisi anak berada dilingkungan keluarganya, masyarakat ataupun dalam lingkungan pendidikan/sekolah. Penyebab paling besar terjadinya tindak kekerasan terhadap anak adalah bahwa pelaku tidak memiliki kesadaran bahwa tindak kekerasan yang dilakukannya akan berpengaruh terhadap pertumbuhan anak baik secara fisik maupun secara mental. Di samping hal tersebut di atas pemahaman hukum terutama yang berkaitan dengan perlindungan anak, masih kurang diketahui dan dipahami, merupakan faktor penyebab terjadinya tindak kekerasan terhadap anak.

Banyak faktor yang menyebabkan anak tidak mau melaporkan tindak kekerasan yang dilakukan terhadapnya kepada orang tua/walinya atau kepada pihak lain yang berwenang. Sebagai contoh adanya perasan takut akibat ancaman pelaku, ditambah kekhawatiran yang akan muncul seperti khawatir mendapatkan tindak kekerasan yang lebih besar dan keterbatasan pengetahuan anak terhadap hal-hal yang dialaminya berkaitan dengan tindak kekerasan. Hal yang terakhir disebut menjadi penyebab banyaknya kasus tindak kekerasan seksual terhadap anak di bawah umur sulit diungkap. Hal ini terjadi karena anak apabila merasakan kepedihan dan kesengsaraan dalam hal ini adalah perlakuan kasar/kekerasan yang dilakukan terhadapnya, maka perasaan tersebut tidak dapat ditampakkan sebab ia merasa enggan, takut dan malu memaparkan perasaannya termasuk kepada orang tuanya. ${ }^{2}$

Survei yang dilakukan Komisi Perlindungan Anak Indonesia (KPAI), menunjukkan sepanjang tahun 2012, tingkat kekerasan di sekolah mencapai 87,6 persen. "Hasil survei yang dilakukan oleh KPAI ini melibatkan 1.026 responden anak," kata Komisioner Bidang

\footnotetext{
${ }^{1}$ Undang-undang nomor 17 tahun 2016 tentang perlindungan anak.

${ }^{2}$ Kartini kartono "Psikologi Anak" Mandar Maju, Bandung, 1995, hlm 140
} 
Pendidikan KPAI, Badriyah Fahyumi, di Jakarta, Senin (30/7). Dari 1.026 anak yang menjadi responden, 87,6\% anak mengaku mengalami tindak kekerasan di lingkungan sekolah dalam berbagai bentuk.

Berbagai hasil tulisan dan hasil penelitian menunjukkan bahwa berbagai tindak kekerasan banyak dialami oleh anak-anak dalam lingkungan sekolah/ pendidikan baik lingkungan pendidikan formal mapun tidak formal. Yang masuk dalam kategori lembaga pendidikan formal antara lain: Sekolah Dasar (SD), Sekolah Menengah Pertama (SMP), Sekolah Menengah Atas (SMA) dan sekolah-sekolah yang sederajat dengan tingkatan sekolah tersebut seperti: Pesantren atau Madrasyah. Adapun pendidikan tidak formal meliputi Taman Kanak-Kanak (TK) atau lembaga-lembaga lain yang mengadakan proses pendidikan seperti kursus atau lembaga bimbingan belajar (bimbel) dan/atau lembaga pelatihan dimana peserta didiknya ialah mereka yang masih tergolong dalam usia anak, sebagaimana yang disebutkan dalam pasal 1 ayat (1) Undang-undang Perlindungan Anak: "Anak adalah seorang yang belum berusia 18 (delapan belas) tahun, termasuk anak yang masih dalam kandungan".

Kekerasan dalam lingkungan pendidikan merupakan masalah sosial yang serius. Dalam dunia pendidikan perbedaan antara ketegasan dengan kekerasan sulit dibedakan. Menurut Abd Rahman Assegaf para pendidik/ guru tidak jarang mengatas-namakan ketegasan untuk melakukan kekerasan terhadap anak didiknya, sehingga bernaung di bawah label "ketegasan" pendidik/guru akan mendapatkan pembenaran atas sikap yang dilakukannya. Jika tindakan tegas yang dilakukan pendidik/guru kepada anak didiknya sudah kelewat batas, artinya sudah berada di luar wewenangnya dan melanggar Hak Asasi Manusia (HAM), itu baru namanya kekerasan. Dengan kata lain, batas antara ketegasan dengan kekerasan sangat tipis. ${ }^{3}$

Dalam Undang-undang Sistim Pendidikan Nasional dikatakan bahwa pendidikan adalah usaha sadar terencana untuk mewujudkan suasana belajar dan proses pembelajaran agar peserta didik secara aktif mengembangkan potensi dirinya untuk memiliki kekuatan spiritual keagamaan, pengendalian diri, kepribadian, kecerdasan, akhlak mulia, serta keterampilan yang diperlukan dirinya, masyarakat, bangsa dan negara. ${ }^{4}$

Perlindungan terhadap anak harus terwujud pula dalam dunia pendidikan. Perlindungan dari berbagai tindak kekerasan yang dilakukan guru, pengelola sekolah atau teman-temannya, baik kekerasan berupa fisik seperti: memukul, menjewer, menampar, menyulut dengan rokok, menendang, meludahi, menjambak, atau kekerasan emosional seperti : memaki, membentak, mencela, mengancam, menakut-nakuti, dan kekerasan seksual, harus benar-benar terwujud karena dalam pasal 54 Undang-undang Perlindungan Anak:

\footnotetext{
${ }^{3}$ Abd Rachman Assegaf "Pendidikan Tanpa Kekerasan"Bernas, Yogyakarta : 2004 hal. 4

${ }^{4}$ Undang-undang Nomor 20 tahun 2003 Tentang Sistem Pendididkan Nasional
} 
"anak di dalam dan di lingkungan sekolah wajib dilindungi dari tindakan kekerasan yang dilakukan guru, pengelola sekolah atau teman-temannya di dalam sekolah yang bersangkutan atau lembaga pendidikan lainnya".

Potret buram perlindungan anak dalam dunia pendidikan setidaknya dapat dilihat dari data hasil penelitian bahwa di Yogyakarta terjadi 28 kasus dari 93 kasus yang ada. Dengan kata lain, 24,7\% kasus kekerasan dalam dunia pendidikan terjadi di Yogyakarta, yang notabene kota pendidikan. Kasus-kasus kekerasan terhadap anak di dunia pendidikan telah dilakukan oleh semua pihak. Tidak hanya dilakukan guru dan kepala sekolah tetapi juga oleh siswa dan masyarakat. Kasus-kasus tersebut terus berkembang karena tidak ada penyelesaiannya. Kekerasan yang terjadipun tidak hanya fisik dan psikis serta seksual tetapi berupa akademis seperti hubungan yang bersifat "top down" antara guru dengan murid yang menciptakan komunikasi satu arah belum lagi model pendidikan yang berat dan tegang dimana bobot materi kurikulum di Indonesia terbanyak dibanding Negara lain, jika Negara lain menerapkan kurikulum bermuatan 35, Indonesia menerapkan 42, apalagi jika ditambah dengan kegiatan ekstra maupun pelajaran tambahan sehingga di Indonesia perlu merubahnya dengan konsep pendidikan damai dengan membangun interaksi humanistik antara pendidik/guru dan anak didik. ${ }^{5}$

Anak-anak mengalami kekerasan dan hukuman badan. Selain kekerasan di dalam rumah (domestic violence), kekerasan dan hukuman badan pada anak-anak juga terjadi di lingkungan sekolah. Kekerasan terhadapa anak-anak juga menurut survei yang dilakukan di Surabaya, melalui pemberitaan harian Memorandum, dari sejumlah 230 kasus yang tercatat, ruang sosiologi kekerasan pada anak-anak terjadi di keluarga (129 kasus), di sekolah (10 kasus), di lembaga keagamaan (2 kasus), di sektor perekonomian (21 kasus). ${ }^{6}$

Ketentuan dalam pasal 54 Undang-undang No. 17 tahun 2016 memerlukan antisipasi dengan pembuatan regulasi dan kultur pendidikan yang bisa menjamin realisasi sekolah yang aman dari kekerasan terhadap anak, sehingga bentuk kekerasan yang dilakukan guru terhadap anak didiknya dapat ditanggulangi.

Dalam KUHPidana, perlindungan terhadap anak dari tindak kekerasan diatur dalam beberapa pasal seperti yang tercantum dalam pasal 285 KUHPidana yang berbunyi :

"Barang siapa dengan kekerasan atau ancaman kekerasan memaksa seorang wanita bersetubuh dengan dia diluar pernikahan, diancam karena melakukan perkosaan, dengan pidana penjara paling lama dua belas tahun".

Perlindungan anak dari tindak penganiayaan dalam KUHpidana, juga termuat dalam pasal 351 ayat (1), ayat (2) dan ayat (3) KUHpidana yang berbunyi :

\footnotetext{
${ }^{5}$ Ibid.

${ }^{6}$ www.republika.co.id / kekerasan anak dan corporal punishment
} 
Ayat (1):"Penganiayaan diancam dengan pidana penjara paling lama dua tahun delapan bulan atau denda paling banyak tiga ratus rupiah".

Ayat (2): "Jika Perbuatan mengakibatkan luka-luka berat yang bersalah dikenakan pidana paling lama lima tahun".

Ayat (3): "Jika mengakibatkan mati, dikenakan pidana paling lama tujuh tahun".

Beberapa pasal dalam KUHPidana tersebut diatas dapat melindungi anak dari kekerasan yang bersipat fisik dan seksual, namun apabila ada seorang guru yang melakukan perbuatan tidak menyenangkan terhadap anak dalam KHUPidana perbuatan tersebut diatur dalam pasal 335 ayat (1) ke-1 yang berbunyi :

Ayat (1) : "Diancam dengan pidana penjara paling lama satu tahun atau denda paling banyak tiga ratus rupiah":

ke-1. "barang siapa secara melawan hukum memaksa orang lain supaya melakukan, tidak melakukan atau membiarkan sesuatu, dengan memakai kekerasan, suatu perbuatan lain maupun perlakuan yang tak menyenangkan, atau dengan memakai ancaman kekerasan, suatu perbuatan lain maupun perlakuan yang tak menyenangkan, baik terhadap orang itu sendiri maupun orang lain."

Menyangkut kekerasan yang bersifat psikis/mental, dalam penjelasan Undangundang Nomor 17 tahun 2016 Pasal 13 ayat (1) huruf a menjelaskan : "Perlakuan kekerasan dan penganiayaan, misalnya perbuatan melukai dan/atau mencederai anak, dan tidak semata-mata fisik, tetapi juga mental dan sosial". Oleh karenanya dalam Undangundang ini perbuatan membentak anak didik dapat dikenai sanksi pidana seperti yang tercantum dalam pasal 8o ayat (1) Undang-undang nomor 17 tahun 2016 yang berbunyi :

"Setiap orang yang melakukan kekejaman, kekerasan, atau ancaman kekerasan, atau penganiayaan terhadap anak dipidana dengan pidana penjara paling lama 3 (tiga) tahun 6 (enam) bulan/atau denda paling banyak Rp.72.000.000,00 (tujuh puluh dua juta rupiah)".

Dalam Perlindungan anak KUHPidana sebagai lex's generalis maupun Undangundang Perlindungan Anak nomor 17 tahun 2016 sebagai lex's specialis merupakan upaya melindungi anak dari tindak kekerasan baik fisik maupun mental/psikis, namun pada kenyataannya banyak anak didik yang masih di bawah umur mendapatkan tindak kekerasan dari gurunya berupa kekerasan fisik, seksual ataupun mental/psikis baik di lingkungan pendidikan formal maupun non-formal tanpa penyelesaian yang adil bagi anak. Hak-hak anak yang diberikan hukum kepada anak belum sepenuhnya bisa ditegakkan, hak-hak anak sebagaimana dimaksud dokumen hukum mengenai perlindungan anak, masih belum cukup ampuh menyingkirkan keadaan buruk bagi anak. ${ }^{7}$ Hal ini yang

${ }^{7}$ Muhammad Joni, Aspek Hukum Perlindungan Anak Dalam Perspektif Konvensi Hak Anak, Citra Aditya, Bandung : 1999. hal .5 
menarik untuk dikajinya permasalahan ini sehingga dapat diketahui dari sisi manakah praturan perundang-undangan yang melindungi anak tidak dapat dilaksanakan secara maksimal.

Pantauan KPAI hanya sebagian kecil kasus yang terjadi pada anak. Hal ini dapat dilihat dari data secara umum bahwa jumlah penduduk Indonesia sebanyak 237,637 juta jiwa, sebanyak 85,7 juta diantaranya anak. Sekitar 40.000 anak yang dieksploitasi secara seksual baik karena korban traffiking maupun dilacurkan. Sekitar 2,5 juta anak korban kekerasan baik fisik, psikis, seksual maupun sosial dan 4,5 juta anak dipekerjakan. Sebanyak 3 juta anak melakukan pekerjaan bahaya. (UNICEF, 11/4/2010). Kementerian Sosial menyebutkan terdapat 4,8 juta anak terlantar. Menyingkapi gambaran buram anak Indonesia ini, tahun 2012 KPAl mengadakan survei di 9 Provinsi yaitu; 1). Jawa Timur; 2). Jawa Tengah; 3). D.I. Yogyakarta; 4). Jawa Barat; 5). Banten; 6). Sumatera Barat; 7). Lampung; 8). Jambi; 9). Kalimantan Timur. Total responden sebanyak 2113 orang. $^{8}$

Fakta kekerasan anak memperlihatkan bahwa; dari 1026 responden anak (SD/MI, SMP/MTs dan SMA/MA) yang berhasil ditemui dan memberikan pengakuannya, tercatat $91 \%$ responden anak mengaku masih mendapatkan perlakuan tindak kekerasan di lingkungan keluarga. Sementara itu $87,6 \%$ responden anak mengaku mengalami tindak kekerasan di lingkungan sekolah sejumlah $17,9 \%$ responden anak yang pernah mengalami bentuk perlakuan kekerasan di lingkungan masyarakat. Survei ini diharapkan mampu mendorong semua pihak untuk melakukan kajian secara mendalam dan pemetaan secara nasional sehingga pemerintah memiliki data yang akurat tentang kekerasan yang terjadi terhadap anak. Data tersebut akan membantu pemerintah dan masyarakat menyusun peraturan, kebijakan, program dan jangkauan untuk pencegahan terjadinya kekerasan pada anak.

Kekerasan di sekolah yang marak terjadi seringkali dibenarkan oleh masyarakat bahkan orang tua dari peserta didik karena tindak kekerasan tersebut merupakan bagian dari proses mendidik anak. Padahal hukuman apapun bentuknya bagi peserta didik, dalam jangka pendek, akan mempengaruhi konsentrasi, persepsi dan perilakunya, hingga tidak tertutup kemungkinan anak menjadi malas belajar atau bahkan sekolah. Pada akhirnya peserta didik tinggal kelas atau berhenti sekolah. Secara psikologis, hukuman di lembaga pendidikan dapat menyebabkan anak menjadi trauma atau antipati terhadap pendidikan. ${ }^{9}$

Kekerasan merupakan operasionalisasi dari pola asuh authoritarian. Pengajar authoritarian berusaha untuk menentukan, mengontrol dan menilai tingkah laku dan

8 Ihsan Tanjung, Tren Kekerasan Pada Anak dan Remaja di Indonesia, http://ihsanpiaman .blogspot.com/2013/o8/tren-kekerasan-pada-anak-dan-remaja-di.html. diakses pada tanggal, 14 Agustus 2018

${ }^{9}$ Syamsuarni, Hukuman di Sekolah dan Hak Anak atas Pendidikan, dalam Kalingga, Edisi MaretApril 2004, Medan, PKPA, hal. 14 
sikap-sikap anak sesuai dengan yang ditentukan, terutama sekali berdasarkan standarstandar yang absolut mengenai perilaku. Pengajar ini menekankan nilai kepatuhan yang tinggi terhadap kekuasaan atau kewenangannya dengan menghukum, memaksa dengan kuat untuk mengekang 'kehendak diri' anak bila perilaku dan keyakinan-keyakinan anak bertentangan dengan apa yang dipandang benar menurut keyakinan dirinya. Dampak pola pengasuhan authoritarian adalah anak menjadi penakut, cemas atau gelisah, suka murung, tidak bahagia, mudah tergganggu dan suka mengganggu, permusuhan secara pasif dan menggunakan tipu daya, mudah stres atau tegang, mudah dongkol dan menarik diri dari masyarakat, serta tidak terarah. ${ }^{10}$

Pemukulan, penghinaan, pengucilan, jika itu dilakukan kepada anak selalu ada rasionalisasinya entah untuk pendidikan, untuk pendisiplinan atau malah dianggap untuk kebaikan. Masyarakat mempunyai anggapan bahwa anak-anak sudah terbiasa dengan tindakan kekerasan dan penghukuman fisik sebagai proses pembelajaran dalam hidupnya. Bahkan, kebisuannya diartikan sebagai kerelaan menerima kekerasan. Anggapan ini mencerminkan adanya relasi yang dominatif antara orang dewasa dan anak yang pada gilirannya salah satu pihak dapat memamerkan kuasa atau dominasinya kepada pihak lain yang dianggap lebih lemah. ${ }^{11}$

Dalam konteks sistem pendidikan kekinian, meminjam analisis Francis Wahono, peserta didik berada pada strata paling bawah. Peserta didik menjadi obyek langsung dari kurikulum yang didukung oleh kerangka dan pranata pendidikan. ${ }^{12}$ Sistem pendidikan ini menganut "banking concept of Education." Peserta didik dalam proses pendidikan model bank yang dipraktikkan di sekolah-sekolah lebih menjadi objek pendidikan, mereka pasif dan hanya mendengar, mengikuti, mentaati dan mencontohi para guru. Praktek pendidikan seperti itu, dalam perspektif Paulo Freire tidak saja bersifat menjinakkan, tetapi bahkan lebih jauh merupakan proses dehumanisasi dan penindasan. ${ }^{13}$ Kondisi demikian menempatkan peserta didik benar-benar berada di bawah kendali sekolah saat pengajar berada dalam posisi lebih tahu dan mengerti. Konsep ini dikatakan Satre sebagai konsep pendidikan yang 'mengunyah' (digenstive) atau memberi makan (nutritive) di mana pengetahuan 'disuapkan' oleh pengajar kepada peserta didik untuk 'mengeyangkan mereka'. Teori dan praktik pendidikan seperti ini mengabdi kepada tujuan-tujuan yang disusun oleh para pendidik dengan menempuh

${ }^{10}$ John Th Ire, mengutip penelitian Baumrind dalam Lerner \& Hullsch, dalam Anakmu Bukanlah Anakmu, www.indomedia.com/poskup/2005/11/og/edisiog/og11pin1.html, diakses pada tanggal 13 September 2018

${ }^{11}$ Lihat Antarini Arna, Analisis Konsultasi Anak Nasional : Kekerasan Terhadap Anak: Agresi Terhadap Martabat Kemanusiaan Anak.

${ }^{12}$ Francis Wahono, Kekerasan dalam Pendidikan : Sebuah Tinjauan Sosio-Ekonomi Didaktika, dalam Gelombang Perlawanan Rakyat : Kasus-Kasus Gerakan Sosial di Indonesia, Yogyakarta, Insist Press, 2003, hal. 232

${ }^{13}$ Lihat Mansour Fakih, Roem Topatimasang, dan Toto Rahardjo, Pendidikan Popular: Membangun Kesadaran Kritis, Yogyakarta, REaD Book, 2000, hal. 38 
cara yang seefisien mungkin. Kekerasan diawali dari sini karena pendidikan gaya bank menghalalkan dipakainya kekerasan untuk menertibkan dan mengendalikan para peserta didik. ${ }^{14}$ Kekerasan di lingkungan dunia pendidikan memang bertaut erat dengan sistem klasifikasi materi pembelajaran yang berdampingan dengan metode pembelajaran bergaya bank. Penyebab internal ini ditambah oleh rangsangan sekolah yang melihat kualitas ditentukan oleh bagaimana membuat peserta didik untuk berada terus menerus dalam kurikulum yang tidak manusiawi dengan jadwal yang amat ketat. ${ }^{15}$

Perlakuan apapun yang menjurus kepada kekerasan terhadap anak tidak dapat dibenarkan, tetapi pada praktiknya banyak sekali tindak kekerasan itu terjadi. Tindak kekerasan terhadap anak dapat berupa fisik, psikis dan seksual.

Di lingkungan pendidikan ada beberapa tindakan yang menjurus pada kekerasan dari hal yang dianggap sebagai hal yang wajar dan lumrah, seperti adanya bentakan kepada anak didik, hukuman yang bersifat fisik seperti lari mengelilingi lapangan upacara atau seorang guru biasa menjewer telinga anak didiknya karena tidak mengerjakan pekerjaan rumah yang ditugaskan kepadanya dan lain sebagainya atau tindakan yang terkategori pelanggaran seperti tindakan yang mengakibatkan luka juga ada tindakan asusila. Dilihat dari motifnya tindak kekerasan itu dilakukan guru terhadap anak didiknya dalam rangka mendidik anak agar lebih disiplin dan takut atau segan kepada guru tetapi hal itu dapat berpengaruh negatif terhadap perkembangan fisik dan mental anak. Menakuti anak sebagai satu cara untuk menanamkan kebiasaan dan disiplin akan menimbulkan fobi atau ketakutan yang tidak wajar pada diri anak tersebut. $^{16}$

Kekerasan yang terjadi terhadap anak yang dilakukan oleh guru seakan sulit untuk diungkap karena tertutupi dengan adanya anggapan bahwa kekerasan itu dilakukan agar anak menjadi disiplin dan taat kepada guru sehingga muncul anggapan sangat wajar apabila guru melakukan kekerasan asal tujuannya menanamkan kedisiplinan terhadap anak didik asal tidak sampai keterlaluan padahal perlakuan kasar dan kekerasan apapun terhadap anak tidak dapat dibenarkan.

Disisi lain eksistensi pendidik seringkali dihadapkan dengan realitas yang tidak mendukung pelaksanaan tugas profesinya. Sebut saja, adanya pengaduan orang tua dan masyarakat terhadap kekerasan yang dilakukan pendidik tatkala melaksanakan tugasnya di sekolah. Undang-undang Perlindungan Anak sesungguhnya merupakan upaya negara untuk melindungi anak Indonesia dari perlakuan yang sewenang-wenang dari orang dewasa, yang dalam konteks ini adalah guru.

Kondisi ini tentu saja berdampak semakin sulitnya guru melaksanakan tugas kependidikan untuk menegakkan kedisiplinan, terutama membina kepribadian anak

\footnotetext{
${ }^{14}$ Lihat Eko Prasetyo, Orang Miskin Dilarang Sekolah, Yogyakarta, Insist Press, 2004, hal. 120

${ }^{15}$ ibid, hal. 122-123

${ }^{16}$ Ibid
} 
dengan akhlak yang terpuji. Dalam dunia pendidikan kita mengenal adanya pemberian punishment (hukuman) dan reward (penghargaan). Keduanya itu merupakan salah satu alat pendidikan untuk meningkatkan prestasi dan menegakkan kedisiplinan di lingkungan sekolah.

Pentingnya perlindungan hukum bagi guru, juga perlu disertai dengan adanya sosialisasi pendidikan hukum bagi para guru. Pemerintah, organisasi profesi, dan Lembaga Swadaya Masyarakat (LSM) yang peduli pendidikan bisa menjadi lembaga yang tepat untuk melakukan sosialisasi tersebut. Hal ini Bertujuan agar guru mengetahui, memahami, sekaligus mampu melaksanakan hak dan kewajibannya.

Perlindungan terhadap profesi guru memang merupakan kewajiban pemerintah, namun di sisi lain gurupun harus turut berperan aktif dalam mengupayakan terwujudnya perlindungan tersebut, seperti ajaran Islam yang menjelaskankan bahwa sebuah kaum tidak akan dapat mengubah nasibnya kecuali mereka sendiri yang melakukannya. Guru harus kritis konstruktif terhadap kebijakan pemerintah dan ikut berpartisipasi dalam perumusan kebijakan publik. Ketika guru merasa dirugikan oleh sebuah kebijakan baik kebijakan sekolah maupun kebijakan pemerintah, maka bisa melakukan langkahlangkah untuk mengkritisi kebijakan tersebut. Untuk dapat melakukan hak dan kewajibannya serta terhindar dari praktik deskriminasi terhadap profesinya maka guru harus mengetahui dan memahami peraturan perundang-undangan tentang pendidikan, khususnya tentang guru seperti: Undang-Undang nomor 20 tahun 2003 tentang Sistem Pendidikan Nasional, UU nomor 14 tahun 2005 tentang Guru dan Dosen, PP nomor 19 tahun 2005 tentang Standar Nasional Pendidikan (SNP), PP nomor 74 tahun 2008 tentang Guru, dan sebagainya.

Guru adalah pendidik profesional dengan tugas utama mendidik, mengajar, membimbing, mengarahkan, melatih, menilai, dan mengevaluasi peserta didik pada pendidikan anak usia dini jalur pendidikan formal, pendidikan dasar, dan pendidikan menengah. ${ }^{17}$ Perlindungan hukum sangatlah penting bagi guru, karena hanya dengan adanya perlindungan hukumlah yang bisa membuat guru-guru pada umumnya akan terbebas dari rasa terancam dari interferensi oknum-oknum terntentu. Dengan demikian nantinya guru tidak akan merasa takut dan ragu untuk mengambil sebuah kebijakan dan tindakan dalam menjalankan tugasnya sebagai guru khususnya dalam membentuk karakter anak bangsa yang berakhak mulia. Hal terpenting dari perlindungan hukum bagi guru adalah implementasinya secara nyata, jangan sampai jaminan ini (perlindungan hukum) hanya ada di atas kertas saja. Semoga dengan adanya perlindungan bagi profesi guru dapat membantu guru dalam melaksanakan tugasnya untuk mewujudkan tujuan dari pendidikan nasional.

Perlindungan hukum di Indonesia terhadap guru diakui memang masih lemah. Hal ini terlihat dari fakta yang menunjukan bahwa selama ini, ketika seorang guru ter-

\footnotetext{
${ }^{17}$ Peraturan Pemerintah Nomor 19 Tahun 2017 Tentang Guru.
} 
kena masalah hukum, khususnya permasalahan hukum yang berkaitan dengan tugasnya sebagai guru, maka guru tersebutpun harus berjuang sendiri. Undang-undang Nomor 14 Tahun 2005 tentang Guru dan Dosen pasal 7 ayat (1) huruf h mengamanatkan bahwa guru harus memiliki jaminan perlindungan hukum dalam melaksanakan tugas keprofesionalan. Selanjutnya pada pasal 39 secara rinci dinyatakan: ${ }^{18}$

(1) Pemerintah, pemerintah daerah, masyarakat, organisasi profesi, dan/atau satuan pendidikan wajib memberikan perlindungan terhadap guru dalam pelaksanaan tugas.

(2) Perlindungan sebagaimana dimaksud pada ayat (1) meliputi perlindungan hukum, perlindungan profesi, serta perlindungan keselamatan dan kesehatan kerja.

(3) Perlindungan hukum sebagaimana dimaksud pada ayat (2) mencakup perlindungan hukum terhadap tindak kekerasan, ancaman, perlakuan diskriminatif, intimidasi, atau perlakuan tidak adil dari pihak peserta didik, orang tua peserta didik, masyarakat, birokrasi, atau pihak lain.

(4) Perlindungan profesi sebagaimana dimaksud pada ayat (2) mencakup perlindungan terhadap pemutusan hubungan kerja yang tidak sesuai dengan peraturan perundangundangan, pemberian imbalan yang tidak wajar, pembatasan dalam menyampaikan pandangan, pelecehan terhadap profesi, dan pembatasan /pelarangan lain yang dapat menghambat guru dalam melaksanakan tugas.

(5) Perlindungan keselamatan dan kesehatan kerja sebagaimana dimaksud pada ayat (2) mencakup perlindungan terhadap risiko gangguan keamanan kerja, kecelakaan kerja, kebakaran pada waktu kerja, bencana alam, kesehatan lingkungan kerja, dan/atau risiko lain.

Berdasarkan uraian undang-undang di atas, terlihat jelas perlindungan bagi guru adalah hal yang mutlak. Sayangnya, dalam kenyataannya masih banyak guru yang bekerja dalam ketidakpastian baik berkaitan dengan status kepegawaiannya, kesejahteraannya, pengembangan profesinya, atau pun advokasi hukum ketika terkena masalah hukum.

Dewasa ini guru yang bertugas mungkin ketakutan jika akan menjatuhkan punishment kepada siswa yang melanggar. Padahal, eksistensi reward dan punishment sangat penting dalam pencapaian tujuan pendidikan. Oleh sebab itu, harus ada keseimbangan antara keduanya. Artinya, jika melanggar, maka konsekuensinya adalah mendapat hukuman. Begitu pula sebaliknya, jika berprestasi, maka penghargaan menjadi alat untuk meningkatkan prestasi itu.

Pada titik ini, guru seringkali berada pada posisi yang dilematis, yaitu antara tuntutan profesi dan ketakutan melanggar undang-undang. Maksudnya, di satu sisi guru diberikan kewajiban agar mampu menghantarkan peserta didik dalam mencapai tujuan pendidikan yang salah satunya adalah menjadikan generasi yang berkarakter (akhlak)

\footnotetext{
${ }^{18}$ Undang-undang Nomor 14 Tahun 2005 tentang Guru dan Dosen
} 
baik. Di sisi lain, ketika mereka berupaya untuk menegakkan kedisiplinan, mereka dihadang oleh ketakutan implikasi pelanggaran hukum.

Dunia pendidikan kini kerap diwarnai kasus pidana. Silang pendapat sering kali berubah menjadi kasus pelik yang berujung pidana. Sejumlah kasus menunjukkan ruang gerak guru dalam mendidik kedisiplinan siswa menjadi lebih longgar karena khawatir dianggap menyalahi aturan perundang-undangan. Liputan6.com mencatat setidaknya terjadi lima konflik pelik yang terjadi di berbagai daerah di Indonesia sepanjang tahun $2016 .^{19}$

Melihat realita tersebut pemerintah akhirnya mengeluarkan Peraturan Pemerintah (PP) nomor 19 tahun 2017 tentang guru dimana salah satu pasal dalam PP tersebut yakni pasal 39 memberikan peluang kepada guru untuk dapat memberikan sanksi kepada siswa. Isi pasal 39 tersebut berbunyi :

"Guru memiliki kebebasan memberikan sanksi kepada peserta didiknya yang melanggar norma agama, norma kesusilaan, norma kesopanan, peraturan tertulis maupun tidak tertulis yang ditetapkan Guru, peraturan tingkat satuan pendidikan, dan peraturan perundang-undangan dalam proses pembelajaran yang berada di bawah kewenangannya."

Sedangkan Pasal 39 Ayat (2) PP No 19 Tahun 2017 menyebutkan Sanksi dapat berupa teguran dan/atau peringatan, baik lisan maupun tulisan, serta hukuman yang bersifat mendidik sesuai dengan kaidah pendidikan, kode etik Guru, dan peraturan perundang-undangan. (3) Pelanggaran terhadap peraturan satuan pendidikan yang dilakukan oleh peserta didik yang pemberian sanksinya berada di luar kewenangan Guru, dilaporkan Guru kepada pemimpin satuan pendidikan. (4) Pelanggaran terhadap peraturan perundang-undangan yang dilakukan oleh peserta didik, dilaporkan Guru kepada pemimpin satuan pendidikan untuk ditindaklanjuti sesuai dengan ketentuan peraturan perundang-undangan.

Isi pasal tersebut tentu saja bertujuan agar guru dapat diberi kebebasan didalam memberikan sanksi kepada siswa, manakala ada siswa yang melanggar aturan di sekolah, namun hal ini terkadang menjadi semacam pembenaran ketika guru memberikan sanksi kepada siswanya yang masih di bawah umur di luar ketentuan dan kewajaran. Adapun jaminan perlindungan guru ada pada Pasal 41 (1) PP tersebut yang menyebutkan: guru berhak mendapatkan perlindungan hukum dari tindak kekerasan, ancaman, perlakuan diskriminatif, intimidasi, atau perlakuan tidak adil dari pihakpeserta didik, orang tua peserta didik, Masyarakat, birokrasi, atau pihak lain.

19 Raden AMP, 5 Konflik Guru Versus Siswa Berujung Pidana. https:// www. liputan6.Com /regional/read/2575357/5-konflik-pelik-guru-versus-siswa-berujung-pidana, diakses pada tanggal 13 September 2018 


\section{Perspektif Psikologis dan Sosiologis Mengenai Tindak Kekerasan yang Dilakukan Terhadap Anak}

Tindak kekarasan baik itu fisik, psikis dan atau seksual yang dilakukan terhadap anak dapat menimbulkan pengaruh baik secara psikologis bagi anak yang menjadi korban maupun secara sosiologis. Dalam perspektif psikologis tindak kekerasan atau kekejaman terhadap anak-anak (child abuse) diawali dari penelantaran anak hingga perkosaan dan pembunuhan. Terry E. Lawson, seorang psikiater anak menyebut empat macam abuse (perlakuan kejam) terhadap anak yakni : ${ }^{20}$ Emotional abuse, Verbal abuse, Physical abuse, dan Sexual abuse.

Anak-anak Indonesia banyak yang mengalami kekejaman (abuse) keempatnya sekaligus secara bersamaan. Satu saja dari keempat abuse itu dilakukan terus menerus akan menyebabkan anak-anak menderita gangguan psikologis.

Emotional abuse terjadi ketika seorang ibu atau seorang guru telah mengetahui anaknya membutuhkan perhatian, tetapi si ibu pada waktu itu menggabaikan dan membiarkan kebutuhan anak untuk diperhatikan. maka anak akan mengingat semua kekerasan emosinal jika kekerasan emosional itu berlangsung secara konsisten. Si ibu yang secara emosional berlaku keji terhadap anaknya akan terus menerus melakukan hal yang sama sepanjang kehidupan anak itu.

Verbal abuse terjadi ketika seorang ibu atau guru, setelah mengetahui anaknya membutuhkan perhatian menyuruh anak itu untuk diam atau prentah dan larangan lain agar anak itu diam, jika anak anak itu tidak menghiraukan perintah tersebut maka si ibu terus menerus melakukan kekerasan verbal seperti memarahi anak dengan kata-kata kasar atau kotor "kamu bodoh", "tolol", "Anjing" dan lain sebagainya. Anak akan mengingat semua kekerasan verbal jika semua kekerasan verbal itu berlangsung dalam satu periode.

Phsyical abuse terjadi ketika seorang ibu atau guru memukul anak (ketika anak sebenarnya membutuhkan perhatian). Memukul anak dengan tangan, kayu, kulit, besi atau logam, maka peristiwa itu akan terus diingat anak, jika kekerasan fisik itu berlangsung dalam periode tertentu.

Sexsual abuse terjadi ketika seorang ayah/ ayah tiri atau guru melakukan perbuatan cabul terhadap anak bahkan sampai dengan menyetebuhi si anak, biasanya jarang terjadi pada usia anak yang relatif masih balita walaupun ada beberapa kasus ketika anak perempun menderita kekerasan seksual dalam usia balita.

Semua tindakan kekerasan dan kekejaman kepada anak-anak akan terus direkam dalam bawah sadar mereka dan akan terus dibawa sampai kepada masa dewasa, dan terus sepanjang hidupnya. Anak yang mendapat perlakuan kejam dari orangtuanya atau gurunya akan menjadi sangat agresif dan setelah menjadi orang tua

\footnotetext{
${ }^{20}$ MIF. Baihaqi, Anak Indonesia Teraniaya, Remaja Rosdakarya, Bandung : 1998.
} 
akan berlaku kejam kepada anak-anaknya. Orangtua agresif melahirkan anak-anak yang agresif, yang pada gilirannya anak-anak tersebut akan menjadi dewasa yang agresif. Kekerasan yang dilakukan orang dewasa kepada anak-anak akan melahirkan anak-anak yang menggunakan kekerasan sebagai cara mengatasi persoalan. Akhirnya, anak-anak itu menjadi orang-orang berusia dewasa yang memperoleh kesenangan dengan melakukan tindakan kekerasan, dan begitulah terus menerus.

Dalam perspektif sosiologis ditemukan bahwa ketika kekerasan kepada anakanak berakibat kepada budaya kekerasan, maka hal tersebut berpindah dari permasalahan personal kepada permasalahan sosial. Tindakan kekerasa adalah salah satu persoalan sosial yang besar pada masyarakat modern. Prersoalan sosial adalah pola prilaku masyarakat atau sejumlah besar anggota masyarakat yang secara meluas tidak dikehendaki masyarakat tetapi disebabkan oleh faktor-faktor sosial dan memperlakukan tindakan sosial untuk mengatasinya. ${ }^{21}$

Kekerasan pada anak-anak merupakan persoalan personal jika hal itu hanya menimpa segelintir anak-anak saja. Sebab-sebabnya dapat dilacak pada sebab-sebab psikologis dari individu yang terlibat yakni korban dan pelaku. Pemecahannya juga dapat dilakukan secara individual. Tetapi jika prilaku kekerasan terhadap anak baik secara fisik, psikis dan seksual terdapat secara meluas di tengah-tengah masyarakat maka permasalahanya tidak lagi sebagai permasalahan personal tetapi sudah menjadi bagian permasalahan sosial. Jika hal tersebut terjadi, maka penyebabnya tidak bisa lagi dilacak pada sebab-sebab individual, melainkan harus dicari pada tataran nilai, pola interaksi, struktur sosial ekonomi masyarakat dan atau pranata sosial. Pemecahannya memerlukan tindakan kolektif dari seluruh elemen masyarakat.

Untuk dapat melihat apakah kekerasan yang terjadi pada anak-anak Indonesia saat ini sudah menjadi permasalahan sosial atau tidak, maka harus dilihat apakah sering ditemukan kejahatan terhadap anak-anak ditengah-tengah masyarakat? Jika ditemukan berbagai tindak kejahatan terhadap anak-anak saat ini, maka kekerasan kepada anakanak sudah menjadi problem sosial di negeri ini. Permasalahan sosial tersebut terjadi akibat beberapa faktor sosial yaitu ${ }^{22}$ : pertama adalah norma sosial dimana tidak ada control sosial pada tindakan kekerasan pada anak-anak, masyarakat menganggap hal yang wajar apabila terjadi kekerasan terhadap anak-anak di tengah-tengah masyarakat seperti contohnya seorang ayah yang menempeleng anaknya yang nakal, atau seorang guru yang memukul muridnya yang nakal dan lain sebagainya dianggap wajar oleh masyarakat.

Faktor sosial kedua adalah nilai-nilai sosial dimana hubungan anak dengan orang dewasa dalam masyarakat berlaku seperti hirarki sosial dimana anak-anak berada pada posisi paling rendah sebagai konsekwensinya anak-anak harus selalu menjalankan keinginan atau perintah orang-orang dewasa sebagai contoh seorang guru dapat menyuruh apa saja muridnya termasuk ketika memberikan hukuman atau sanksi apabila

\footnotetext{
${ }^{21}$ MIF. Baihaqi. Ibid.

${ }^{22}$ Ibid.
} 
perintahnya itu tidak dilaksanakan maka guru mengancam tidak akan memberikan nilai bagus, atau anak itu tidak akan naik kelas dan lain sebagainya.

Faktor sosial yang ketiga adalah ketimpangan sosial dimana kita akan menemukan bahwa para pelaku dan anak korban kekerasan kebanyakan berasal dari kalangan sosial ekonomi yang rendah. Kemiskinan, yang tentu saja masalah sosial lainya yang lahir dari struktur ekonomi dan politik yang menindas, telah melahirkan semacam subkultur kekerasan. Karena tekanan ekonomi seorang orang tua atau guru mengalami stress yang berkepanjangan ia akan mudah cepat marah dan itu sangat berpeluang untuk melakukan kekerasan kepada anak baik fisik, psikis ataupun sosial.

\section{Faktor Penyebab Terjadinya Tindak Kekerasan Guru Terhadap siswa}

Kekerasan terhadap anak yang dilakukan oleh kalangan pendidik dalam hal ini adalah guru bukan merupakan hal baru dalam catatan kejahatan yang dilakukan terhadap anak dalam lingkungan pendidikan/sekolah seperti yang ditulis oleh Abd Rachman Assegaf dalam bukunya Pendidikan Tanpa Kekerasan, yang menyebutkan potret buram perlindungan anak dalam dunia pendidikan setidaknya dapat dilihat dari data hasil penelitian bahwa di Yogyakarta terjadi 28 kasus dari 93 kasus yang ada. Dengan kata lain, 24,7 Persen kasus kekerasan dalam dunia pendidikan terjadi di Yogyakarta. ${ }^{23}$

Setidaknya ada dua faktor yang menyebabkan terjadinya tindak kekerasan guru terhadap anak didiknya yang masih dibawah umur yakni : pertama adalah faktor personal yaitu yang disebabkan oleh individu baik guru sebagai pelaku maupun anak didik yang masih dibawah umur sebagai korban tindak kekerasan guru tersebut.

Berkaitan dengan individu guru sebagai pelaku kekerasan terhadap anak didik dapat disebabkan dua hal yakni pemahaman yang rendah terhadap arti penting mulianya seorang anak sebagai manusia genersasi penerus yang hal itu merupakan bagian dari ketidak tahuan dan pemahaman akan peraturan perundang-undangan yang mengatur mengenai anak khususnya Undang-undang Nomor 17 tahun 2016 Tentang Perlindungan Anak, yang semestinya dipahami dan dimengerti oleh guru bahwa anak harus dilindungi dari segala bentuk kekejaman dan kekerasan baik kekerasan fisik, kekerasan psikis maupun kekerasan seksual.

Hal kedua yang sering membuat guru melakukan tindak kekerasan terhadap anak didiknya yang masih dibawah umur adalah adanya anggapan bahwa untuk mendidik anak didiknya, seorang guru dapat melakukan apa saja. Termasuk dalam menanamkan disiplin pada anak didik yang masih dibawah umur, dengan memberikan sanksi seperti bentakan disertai tamparan, perintah lari mengelilingi lapangan olahraga hingga anak tersebut terlihat kelelahan, atau bahkan menyuruh anak untuk memakan rumput seperti halnya yang dialamai oleh anak-anak pelajar Sekolah Dasar Negeri 030370 Kabupaten Sidikalang yang menerima sanksi dari kepala sekolah mereka akibat melanggar atauran. ${ }^{24}$

\footnotetext{
${ }^{23}$ Abd Rachman Assegaf, ibid.

${ }^{24}$ MIF. Baihaqi. HIm. 63.
} 
Sesungguhya menakuti anak sebagai satu cara untuk menanamkan kebiasaan dan disiplin akan menimbulkan fobia atau ketakutan yang tidak wajar pada diri anak tersebut. ${ }^{25} \mathrm{Hal}$ tersebut akan berdampak negatif bagi perkembangan anak di masa yang akan datang. Hal tersebut jarang dipahami oleh guru yang melakukan kekersasan kepada anak didiknya sahingga batas ketegasan dan kekerasan menjadi samar.

Berkaitan dengan faktor personal anak didik yang masih di bawah umur sebagai korban tindak kekerasan gurunya adalah bahwasanya tindak kekerasan guru baik fisik, psikis maupun seksual akan terjadi secara terus menerus karena jarang diungkap sebagai salah satu akibat anak yang menjadi korban kekerasan tidak menceritakan atau melaporkan kejadian kekerasan gurunya kepada orangtua, temannya atau aparat penegak hukum dikeranakan ada perasaan takut akibat ancaman pelaku atau rasa malu hal ini merupakan hal yang wajar yang muncul dari kebiasaan anak. Anak ketika mengalamai penderitaan jarang mengungkapkanya walaupun kepada orang tuanya sendiri. ${ }^{26}$ Apabila diamati masalah kejahatan menurut proposi yang sebenarnya secara dimensional, maka mau tidak mau kita harus memperhitungkan peranan sikorban dalam timbulnya suatu kejahatan. ${ }^{27}$

Faktor kedua yang sering menjadi penyebab terjadinya tindak kekerasan guru terhadap anak didiknya yang masih dibawah umur adalah faktor sosial, faktor ini muncul ketika masyarakat khususnya dilingkungan pendidikan/ sekolah menganggap wajar apabila ada seorang guru yang melakukan kekerasan terhadap anak didik yang masih dibawah umur, contoh guru yang menyuruh anak didik lari mengelilingi lapangan olah raga hingga anak tersebut kelelahan, menempeleng disertai kata-kata kasar atau anak didik tersebut di jemur diterik sinar matahari menghadap tiang bendera akaibat tidak mengerjakan tugas atau melanggar atauran lainya yang terkadang menjadi sangat wajar hal-hal tersebut untuk dilakukan oleh seorang guru.

Bentuk kekerasan terhadap anak bukan merupakan isu yang berkembang di Negara Indonesia saja tetapi telah menjadi isu internasional dengan melihat data bahwa di Bardabos, 70 persen orang tua umumnya menyetujui hukuman badan (corporal punisment), dan 76 persen menyetujui pemukulan dengan ikat pinggang (belt). Di Cili, dalam survei tahun 1995 diperoleh data bahwa 80 persen orang tua anak yang bersekolah di sekolah negeri dan 57 persen anak yang bersekolah di swasta menggunakan hukuman badan. Di Korea 97 persen, Kuwait 54 persen, dan beberapa negara lain yang dicatat dalam laporan berjudul Ending Corporal Punishment of Children - Making It Happen. ${ }^{28}$

Faktor sosial lainya adalah penanaman bentuk kurikulum pendidikan yang tidak damai bagi anak yakni adanya hubungan satu arah antara pengajar dan pelajar sehingga

\footnotetext{
${ }^{25}$ Kartini kartono. Ibid.

${ }^{26}$ Ibid.

${ }^{27}$ Arif Gosita, Masalah Perlindungan Anak, Akademika Prtessindo, Jakarta : 1989 hal. 73

28 http://www.republika.co.id, http://www.crin.org/en/docs/resources/treaties/crc.28/SC-UK-ESS.pdf, diakses pada tanggal 13 September 2018
} 
apapun yang diperintahkan oleh pengajar, pelajar harus selau patuh mengikuti dan menuruti perintah tersebut. Hal tersebut diperburuk dengan model pendidikan yang berat dan tegang dimana bobot materi kurikulum di Indonesia terbanyak dibanding Negara lain, jika Negara lain menerapkan kurikulum bermuatan 35, Indonesia menerapkan 42, apa lagi jika ditambah dengan kegiatan ekstra maupun pelajaran tambahan sehingga di Indonesia perlu merubahnya dengan konsep pendidikan damai dengan membangun interaksi humanistik antara pendidik/guru dan anak didik. ${ }^{29}$

\section{Upaya Yang Dapat Dilakukan Untuk Mengatasi Terjadinya Tindak Kekerasan Guru Terhadap Anak Didiknya Yang Masih Dibawah Umur.}

Tindak kekerasan guru terhadap anak didiknya yang masih dibawah umur masih tetap terus terjadi walaupun hal itu sulit untuk diungkap tanpa penyelesaian yang tuntas dan tegas. Anak selalu menerima ketidak adilan dari apa yang dialaminya terutama dalam hal mendapatkan keadilan hukum baginya. Tindak kekerasan yang dilakukan gurunya seakan terus berlangsung tanpa ada upaya untuk mencegah dan mengakhirinya.

Sebagai contoh terbaru ditahun 2017 ini telah terjadi pencabulan terhadap anak didik yang masih dibawah umur yaitu terjadi di Kabupaten Karang Asem Bali dimana seorang guru olah raga SDN Karang Asem, melakukan perbuatan cabul terhadap 14 orang murid perempuanya dengan alasan untuk menguji keterampilan olah raganya perbuatan ini telah dilakukan oleh pelaku dalam waktu yang telah cukup lama. ${ }^{30}$

Dalam mengatasi berbagai tindak kekerasan yang dilakukan guru terhadap anak didiknya yang masih dibawah umur, dapat dilakukan dengan dua cara yakni cara pencegahan dan cara penindakan. Cara pencegahan dilakukan agar tindak kekerasan yang dilakukan guru terhadap anak didiknya tidak terjadi atau setidaknya tidak terulang untuk kedua kalinya

Proses pencegahan dapat diawali dengan melakukan pendekatan personal dengan mengadakan penyuluhan atau memahamkan kepada individu, dalam hal ini adalah guru, yang sering menjadi pelaku kekerasan bahwa pendidikan terhadap anak harus mengedepankan nilai-nilai yang bebas dari kekejaman dan kekerasan terhadap anak didik. Di samping itu dibentuk pula kurikulum pendidikan yang damai bagi anak sebagai peserta didik serta pemahaman Peraturan Perundang-undangan yang melindungi anak terutama Undang-undang Nomor 17 Tahun 2016 Tentang Perlindungan anak. Penerangan tidak hanya diberikan kepada guru, namun juga kepada anak termasuk orang tua bahwa mereka memiliki hak mengadukan segala bentuk kekeliruan yakni tindak kekerasan yang dilakukan oleh guru baik kekerasan fisik, psikis ataupun kekerasan seksual. Mereka berhak untuk mengadukan tindak kekerasan tersebut kepada

\footnotetext{
${ }^{29}$ Abd Rachman Assegaf, Ibid.

${ }^{30}$ Berita Kriminal RCTI, "Sergap" Edisi 3 Januari 2005.
} 
lembaga yang telah ditunjuk dalam masalah perlindungan anak yakni Komisi Perlindungan Anak Indonesia (KPAI) atau Komisi Nasional Hak Asasi Manusia (KOMNAS HAM) karena sesungguhnya tindak kekerasan yang dilakukan terhadap anak, juga merupakan bagian dari pelanggaran terhadap Hak Asai Manuasia (HAM).

Upaya lainnya yaitu dengan cara penindakan yang tegas kepada pelaku kekerasan denga memberikan sanksi pidana yang. Pemberian sanksi ini harus sesuai dengan Undang-undang yang berlaku yakni Undang-undang Nomor 23 Tahun 2002 Tentang Perlindungan Anak. Selain diberikan sanksi pidana, sanksi administratif juga dapat diberikan kepada guru sebagai pelaku yakni dengan cara menurunkan pangkat atau golongannya, memindahkan tempat tugasnya kedaerah lain menahan kenaikan jabatan dan lain sebagainya hal ini dapat dilakukan agar pelaku kekerasan terhadap anak yakni guru tidak mau mengulangi perbuatan yang kelirunya itu.

Segala bentuk sanksi pidana hanya dapat diterapkan terhadap pelanggar Undang-undang Perlindungan Anak apabila supremasi hukum di Negara ini benar-benar diwujudkan, hal ini tentunya menjadi kewajiban semua pihak yaitu individu, masyarakat, lembaga-lembaga perlindungan anak, lembaga peradilan, aparat penegak hukum serta pemerintah/ Negara untuk saling membantu dan mengawasi berjalanya Peraturan Perundang-undangan yang melindungi anak agar segala bentuk ketidak adilan dan kekerasan terhadap anak dapat dihilangkan.

Dengan upaya-upaya tersebut diatas segala bentuk kekerasan terhadap anak akan teratasi atau minimal ditekan angka kejadianya sehingga penderitaan yang panjang anak-anak didik yang masih dibawah umur akan segera berakhir.

Seorang guru yang paham akan hak-hak anak, guru yang mengerti akan Peraturan Perundang-undangan yang melindungi anak, anak dan orang tua yang paham akan hak dan kewajiban sebagai korban kekerasan serta masyarakat baik masyarakat secara umum atau masyarakat secara khusus yakni masyarakat sekolah yang paham dan mengerti akan hak anak untuk hidup dan mengenyam pendidikan secara damai serta perhatian seluruh elemen masyarakat dan negara akan hak anak tersebut merupakan hal yang utama untuk terwujudnya pendidikan yang bebas dari tindak kekersan terhadap anak.

\section{Penutup}

Undang-undang nomor 17 tahun 2016 Tentang Perlindungan Anak, telah secara tegas melindungi anak dari berbagai tindak kejahatan seperti diskriminasi, eksploitasi, baik ekonomi maupun seksual, penelantaran, kekejaman, kekerasan, penganiayaan, ketidak adilan dan berbagai perlakuan salah lainya. Secara tegas pula Undang-undang ini memberikan acaman pidana yang berat bagi pelaku-pelaku tindak pidana tersebut di atas. 
Penyebab terjadinya tindak kekerasan yang dilakukan guru terhadap anak didiknya yang masih dibawah umur disebabkan oleh dua faktor yakni faktor personal dari individu pelaku dan korban. Pelaku tidak menyadari dan tidak mengetahui pengaruh negatif tindakan kekerasan bagi si anak. Adapun anak yang menjadi korban kekerasan jarang menceritakan atau melaporkan kekerasan yang dialaminya karena malu atau takut terhadap ancaman pelaku, sehingga tindak kekerasan itu berlangsung lama dan dilakukan terus-menerus. Faktor kedua adalah faktor sosial, dimana masyarakat menganggap wajar terhadap perilaku kasar terhadap anak-anak, mengingat hubungan yang mirip hirarki sosial antara anak dengan orang dewasa, sehingga sering ditemukan anak harus selalu menurut perintah orangtua atau guru apapun perintah itu. Di samping itu, faktor rendahnya status sosial dan ekonomi masyarakat berpengaruh pula pada kebiasaan melakukan kekerasan terhadap anak terutama di lingkungan sekolah.

Upaya yang dapat dilakukan untuk mengatasi permasalahan tersebut di atas adalah melalui pencegahan dan penindakan. Tindakan pencegahan yang dimaksud antara lain melalui sosialisasi perundang-undangan dan pengetahuan yang luas tentang arti pentingnya seorang anak oleh berbagai pihak terutama pemerintah/Negara. Adapun upaya penindakan dilakukan melalui penegakan hukum pidana terhadap pelaku tindak kekerasan sehingga supremasi hukum dapat benar-benar terwujud dalam masyarakat.

\section{Daftar Pustaka}

Assegaf, Abd Rachman. 2004. Pendidikan Tanpa Kekerasan. Yogyakarta: Bernas. Atmasasmita, Romli. 1988. Teori dan Kapita Selekta Kriminologi. Bandung: Eresco.

DEPKEH RI :V.

$$
\text { 1992. Masalah Santunan Terhadap Korban Tindak Pidana, V }
$$

Baihaqi, MIF. 1998. Anak Indonesia Teraniaya. Bandung: Remaja Rosdakarya.

Elmina Marta, Aroma. 2003. Perempuan Kekerasan dan Hukum. Jogjakarta : UI Pres.

Gosita, Arif. 1989. Masalah Perlindungan Anak. Jakarta : Akademika Prtessindo.

Joni, Muhammad. t.th. Aspek Hukum Perlindungan Anak Dalam Perspektif Konvensi Hak

Anak.Bandung: Citra Aditya.

Kartono, Kartini. 1995. Psikologi Anak.Bandung: Mandar Maju.

Lamintang, P.A.F. 1994. Dasar-dasar Hukum Pidana Indonesia. Jakarta: Sinar Baru.

Marpaung, Laden. 1991. Unsur-unsur Perbuatan Yang Dapat Dihukum. Jakarta: Sinar Grafika.

Moeljatno, 1985. Azas-azas Hukum Pidana. Jakarta: Rimka Cipta.

Prinst, Darwan. 2003. Hukum Anak Indonesia. Bandung: Citra Aditya Bakti.

Purnomo, Bambang. 1994. Azas-azas Hukum Pidana, Jakarta: Ghalia Indonesia.

Sahetapy, J.E. 1995. Bunga Rampai Viktimisasi Karya Para Pakar Hukum. Bandung: Eresko.

Soekanto, Soerjono dan Pudji Santoso. 1985. Kamus Kriminologi. Jakarta: Galia Indonesia.

Soesilo, R. 1974. Pokok-Pokok Hukum Pidana. Bogor: Politea. 
Soetejo, Wagiati. 2002. Pengantar Hukum Pidana Anak, Bandung : Refikaaditama Tresna, R. 1959. Azas-azas Hukum Pidana. Jakarta: Tiara. 